\title{
Identification of Powdery Mildew Responsive Genes in Hevea brasiliensis through mRNA Differential Display
}

\author{
Xiang $\mathrm{Li}^{1}$, Zhenghong $\mathrm{Bi}^{2}$, Rong $\mathrm{Di}^{1,3}$, Peng Liang ${ }^{1}$, Qiguang He ${ }^{1}$, Wenbo Liu ${ }^{1}$, \\ Weiguo Miao ${ }^{1, *}$ and Fucong Zheng ${ }^{1, *}$ \\ 1 College of Environment and Plant Protection, Hainan Key Laboratory for Sustainable Utilization of \\ Tropical Bioresource, Hainan University, No. 58, Renmin Avenue, Haikou 570228, China; \\ lixiaoxiao1986@hotmail.com (X.L.); dirong@comcast.net (R.D.); jpdiary@163.com (P.L.); \\ hqg11300817@163.com (Q.H.); saucher@hainu.edu.cn (W.L.) \\ 2 College of Agriculture, Hainan University, Haikou 570228, China; bizhenghong9999999@163.com \\ 3 Department of Plant Biology and Pathology, Rutgers, the State University of New Jersey, 59 Dudley Road, \\ New Brunswick, NJ 08901, USA \\ * Correspondence: weiguomiao1105@126.com (W.M.); zhengfucong@126.com (F.Z.); \\ Tel.: +86-898-6627-0229 (W.M. \& F.Z.); Fax: +86-898-6619-2915 (W.M. \& F.Z.)
}

Academic Editor: Jianhua Zhu

Received: 5 December 2015; Accepted: 22 January 2016; Published: 29 January 2016

\begin{abstract}
Powdery mildew is an important disease of rubber trees caused by Oidium heveae B. A. Steinmann. As far as we know, none of the resistance genes related to powdery mildew have been isolated from the rubber tree. There is little information available at the molecular level regarding how a rubber tree develops defense mechanisms against this pathogen. We have studied rubber tree mRNA transcripts from the resistant RRIC52 cultivar by differential display analysis. Leaves inoculated with the spores of $O$. heveae were collected from 0 to $120 \mathrm{hpi}$ in order to identify pathogen-regulated genes at different infection stages. We identified 78 rubber tree genes that were differentially expressed during the plant-pathogen interaction. BLAST analysis for these 78 ESTs classified them into seven functional groups: cell wall and membrane pathways, transcription factor and regulatory proteins, transporters, signal transduction, phytoalexin biosynthesis, other metabolism functions, and unknown functions. The gene expression for eight of these genes was validated by qRT-PCR in both RRIC52 and the partially susceptible Reyan 7-33-97 cultivars, revealing the similar or differential changes of gene expressions between these two cultivars. This study has improved our overall understanding of the molecular mechanisms of rubber tree resistance to powdery mildew.
\end{abstract}

Keywords: rubber tree; Oidium heveae; differential gene expression; ESTs

\section{Introduction}

The rubber tree (Hevea brasiliensis) is the only economical natural source for natural rubber, which cannot be replaced by artificial synthetic polymers [1,2]. Powdery mildew caused by Oidium heveae B.A. Steinmann is a worldwide leaf disease affecting rubber tree growth [3]. O. heveae attacks immature leaves, causing defoliation and curling of leaves, growth retardation, and reduction in latex yield [4]. Presently chemical application is the main method to control this rubber tree disease, but it is time consuming and labor intensive. Using resistant cultivars is considered more effective and environmentally friendly than chemical application. Therefore, it is important to investigate genes related to powdery mildew defensive mechanisms in the rubber tree. Plants have developed a variety of defensive mechanisms against pathogen attacks [5]. In response to pathogen infection, various plant genes are regulated to resist the challenge from pathogens. Cloning host resistance genes will be 
helpful to understand the mechanism of plant resistance to pathogens at the molecular level and to develop resistant cultivars by the transgenic approach. Unfortunately, none of the resistance genes has been isolated from the rubber tree and there is little information available regarding the defense mechanisms of the rubber tree against $O$. heveae [3].

In this study, we conducted differential display analysis on a resistant rubber tree cultivar at different infection stages to evaluate the gene regulations at the transcriptome level and to identify differential gene expression changes from the interaction of resistant rubber tree with $O$. heveae. The Differential Display Reverse Transcriptase Polymerase Chain Reaction (DDRT-PCR) method was first reviewed in 1992 [6]. It later became one of the major tools to identify and clone genes that were differentially expressed at different states in a given tissue [7].

We then used the quantitative qRT-PCR method to validate and assess the expression changes of eight genes in two rubber tree cultivars: RRIC52, which is highly resistant; and Reyan 7-33-97, which is mildly susceptible to powdery mildew [8]. A resistant plant will rapidly activate gene expressions and produce defense responsive compounds to enhance or induce resistance and prevent pathogen colonization. We aimed to identify the responsive genes expressed during powdery mildew infection in the resistant cultivar RRIC52. The expression changes of these genes were also compared between the resistant RRIC52 and the susceptible Reyan 7-33-97 cultivars.

\section{Results}

\subsection{Comparison of Powdery Mildew Resistance between RRIC52 and Reyan 7-33-97}

To compare the difference of disease resistance between RRIC52 and Reyan 7-33-97, both cultivars were infected with powdery mildew pathogen O. heveae (Figure 1). On Reyan 7-33-97 leaves, powdery mildew grew densely and the leaves were completely covered with the fungus after $120 \mathrm{~h}$ post inoculation (hpi). However, the white powdery colonies were not visible on the upper leaf surface of RRIC52, indicating its resistance to powdery mildew. Moreover, microscopic observation revealed fewer hyphae and conidiophores of powdery mildews produced on the leaf of RRIC52 than Reyan 7-33-97. These results indicate that RRIC52 was more resistant to O. heveae than Reyan 7-33-97.

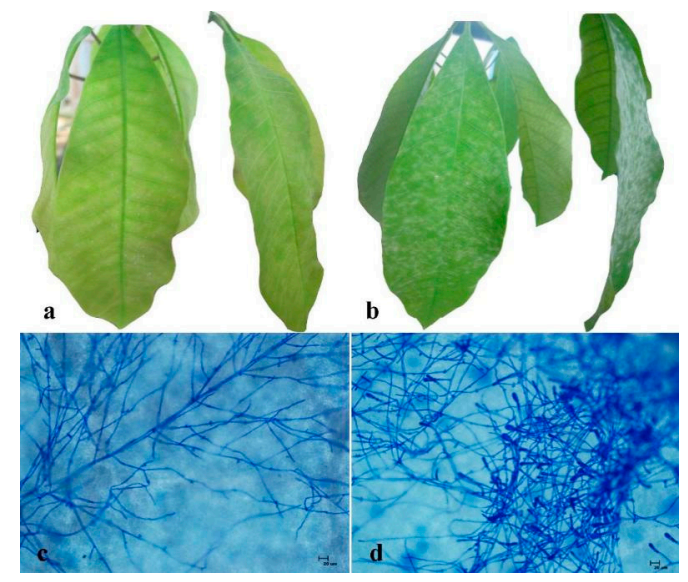

Figure 1. Disease resistance comparison between the highly resistant RRIC52 (a) and the mildly susceptible Reyan 7-33-97 (b) infected with powdery mildews at $120 \mathrm{~h}$ post inoculation; Microscopic observation of the powdery mildew hyphae on the leaves of RRIC52 (c) and Reyan 7-33-97 (d). Bar $=20 \mu \mathrm{m}$.

\subsection{Identification and Isolation of Differentially Expressed Transcripts}

The DDRT-PCR was performed using random combinations of one base-anchored 3'-oligo (dT) primer and one arbitrary primer to amplify the single-stranded cDNAs produced from the total RNA 
samples of RRIC52 at 0 (control), 12, 24, 72, and $120 \mathrm{hpi}$, respectively. After separating on a 6\% urea-polyacrylamide gel, the DNA bands up- or down regulated following pathogen infection were selected and excised from the gel (Figure 2). Approximately 300 differentially expressed DNA bands were selected and used as templates for the second round of PCR amplification. The second round of PCR produced single DNA bands (Supplementary Material, Figure S1) that were verified by reverse Northern dot blot hybridization with the probes synthesized from the RNA samples that were used in the differential display analysis (Figure 3).

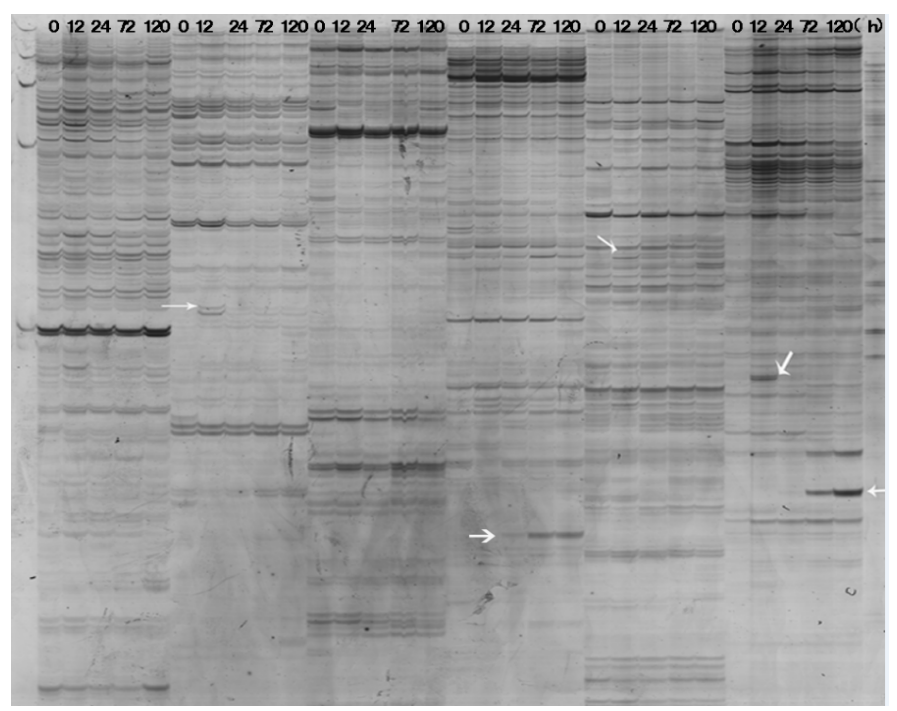

Figure 2. Polyacrylamide gel electrophoresis of partial differentially expressed DNAs (indicated by arrows) amplified by DDRT-PCR from the total RNA samples of RRIC52. Each lane indicates sample from $0,12,24,72$, or 120 hpi. Primer sets for each sample group from left to right are H-T11 A and H-AP27, H-T11 A and H-AP28, H-T11 A and H-AP29, H-T11 A and H-AP30, H-T11 A and H-AP30, and H-T11 A and H-AP30.
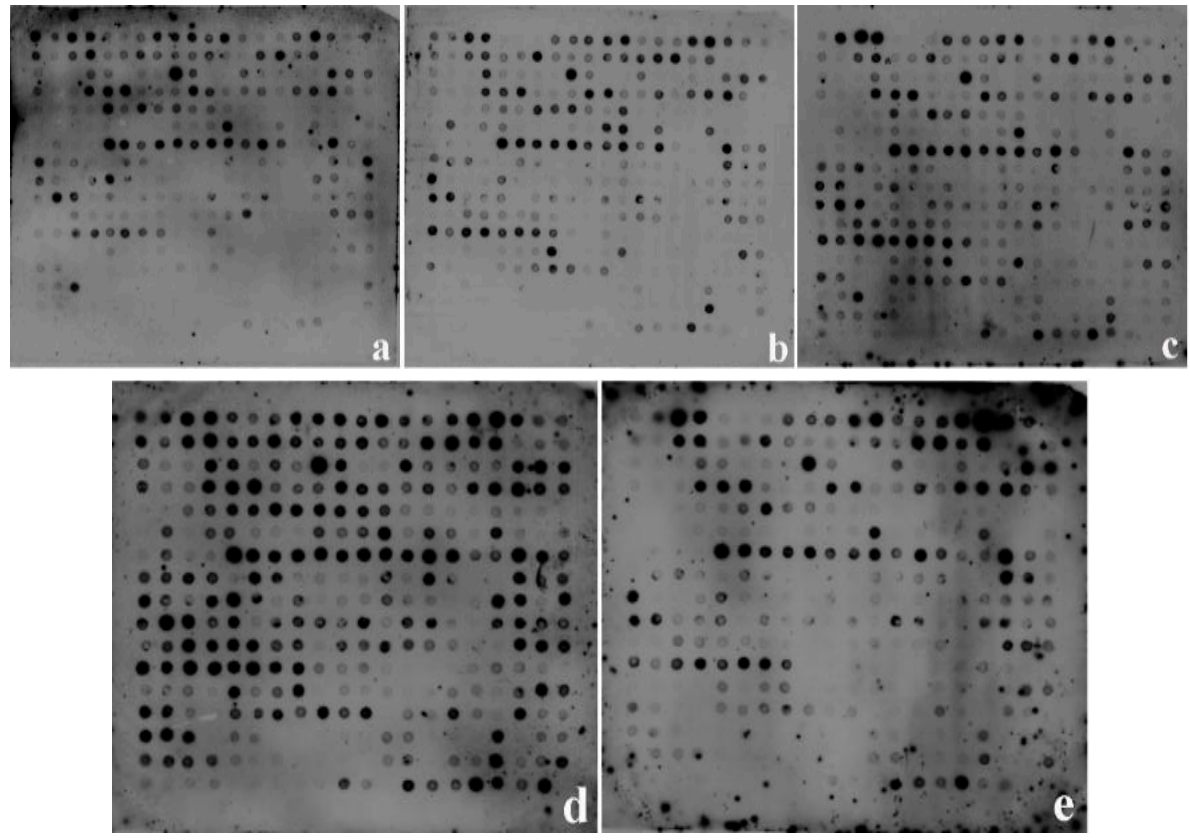

Figure 3. Reverse Northern dot blot analysis of differentially expressed genes. Cloned cDNAs were amplified, denatured, and blotted on five nylon membranes as described. Membranes were hybridized with DIG-labeled total cDNAs from control. (a) 0 hpi; (b) 12 hpi; (c) 24 hpi; (d) 72 hpi; (e) 120 hpi. 


\subsection{Sequence Analysis Revealed the Significances of Differentially Expressed RRIC52 Transcripts}

The EST bands from the DDRT-PCR reactions were selected and cloned into pMD19T (Takara, Kusatsu, Japan) cloning vector and transformed into competent $\mathrm{DH} 5 \alpha$ cells. These ESTs were re-amplified and verified by reverse Northern dot blot hybridization. After sequencing, 78 unique ESTs were deposited in the EST database of GenBank [9] under the library accession number LIBEST-028598. The sequences of these 78 differentially expressed transcripts were compared with BLASTx and BLASTn searches against non-redundant protein sequences and nucleotide sequences in the available NCBI databases. The homology searches showed that these sequences were significantly similar to known genes of other plant species involved in stress response. These EST sequences were classified into seven functional groups: cell wall and membrane pathways, transcription factor and regulatory proteins, transporters, signal transduction, phytoalexin biosynthesis, other metabolism functions, and unclear ESTs. The results of this analysis of the detailed information are summarized in Table 1 and we have also tabulated 78 ESTs with their fragment lengths, the time point when they were excised, and the primer combination in Table S1 (Supplementary Material). Additionally, the mapping of 78 ESTs to the reference genome is supplied in Table S2 (Supplementary Material), and the redundancy for 78 ESTs by blastn (BLAST 2.2.29+, $E$-value $=1 \times 10^{-10}$ ) is analyzed in Table S3 (Supplementary Material).

\subsection{Characterization of the Differentially Expressed ESTs}

In the library, eight ESTs are shown to be involved in cell wall and membrane pathways. These include transcripts for one pectin esterase, four chitinases, one $\beta-1,3$-glucanase, and two germin-like proteins.

Another eight ESTs are highly similar to the predicted transcription factor and regulatory genes, including three WRKY transcription factors, a rop guanine nucleotide exchange factor, a ferritin gene, an eukaryotic initiation factor, and a transcription factor.

There are also 10 ESTs involved in transport activities. These include one clathrin assembly protein and one clathrin light chain, two DNA-directed RNA polymerase II sequences, two glycosyl transferase genes, one flavonol 4'-sulfotransferase, and one lipid-transfer protein.

There are 16 ESTs identified as genes associated with signal transduction, including four serine-threonine protein kinase genes, six kinase protein genes, one signal transducer and transcription activator gene, and two membrane pathways genes.

Eleven ESTs are shown to be involved in phytoalexin biosynthesis. These include transcripts for cytochrome P450, chalcone synthase (CHS), senescence-related gene, UDP-glucosyltransferase, leucoanthocyanidin dioxygenase. 1-Aminocyclopropane-1-carboxylate oxidase, geranyl pyrophosphate synthase. acireductone dioxygenase, short chain alcohol dehydrogenase, and galactinol synthase family protein.

ESTs involved in other metabolic pathways include photosystem related protein, ribosomal protein, ribulose-1, 5-bisphosphate, and special function proteins, which are usually involved in the stress responses of plants. 
Table 1. List of ESTs differentially expressed in the resistant RRIC52 following O. heveae infection and their similarity to known proteins determined by BLAST analysis.

\begin{tabular}{|c|c|c|c|c|c|c|c|}
\hline ESTs & dbEST_Id & Accession No & Homology Found with & Homologous Species & Identity \% & Description & $E$-Value \\
\hline \multicolumn{8}{|c|}{ ESTs in cell wall and membrane pathways } \\
\hline $\mathrm{HBOH} 2$ & 79640384 & JZ822682 & XM_002522813.1 & Ricinus communis & 85.47 & pectinesterase-2 precursor, putative & $2 \times 10^{-87}$ \\
\hline $\mathrm{HBOH} 3$ & 79721589 & JZ893198 & $\mathrm{U} 48687.1$ & Castanea sativa & 78.07 & endochitinase & $3 \times 10^{-164}$ \\
\hline HBOH5 & 79721590 & JZ893199 & AB367524.1 & Arabidopsis thaliana & 66 & CERK1 mRNA for chitin elicitor receptor kinase 1 & $1.00 \times 10^{-100}$ \\
\hline $\mathrm{HBOH} 7$ & 79640387 & JZ822685 & XM_002530816.1 & Ricinus communis & 84.47 & glucan endo-1,3-beta-glucosidase precursor, putative & $3 \times 10^{-149}$ \\
\hline HBOH15 & 79721594 & JZ8931203 & XM_006375808.1 & Populus trichocarpa & 80.33 & germin-like protein 1 & $6 \times 10^{-72}$ \\
\hline НBOH66 & 79761733 & JZ897003 & XM_006376356.1 & Populus trichocarpa & 81.84 & class IV chitinase family protein & $2 \times 10^{-132}$ \\
\hline HBOH67 & 79761734 & JZ897004 & XM_002532766.1 & Ricinus communis & 80.94 & chitinase 1 precursor, putative & $3 \times 10^{-118}$ \\
\hline HBOH68 & 79761735 & JZ897005 & AY973617.1 & Manihot esculenta & 88.24 & germin-like protein GLP partial CdS & $2 \times 10^{-163}$ \\
\hline \multicolumn{8}{|c|}{ ESTs involved in transcription factor and regulatory proteins } \\
\hline $\mathrm{HBOH} 4$ & 79640385 & JZ822683 & XM_002526622.1 & Ricinus communis & 86.35 & ferritin, plant, putative & $7 \times 10^{-171}$ \\
\hline НВOH13 & 79721592 & JZ8931201 & XM_002303816.2 & Populus trichocarpa & 78.24 & WRKY transcription factor 40 family protein & $3 \times 10^{-85}$ \\
\hline HBOH14 & 79721593 & JZ8931202 & XM_012596852.1 & Gossypium raimondii & 58 & WRKY transcription factor 18-like & $7 \times 10^{-15}$ \\
\hline НВOH31 & 79761701 & JZ896971 & XM_002534015.1 & Ricinus communis & 87.56 & eukaryotic initiation factor iso-4F subunit p82-34, putative & $3 \times 10^{-62}$ \\
\hline НВОН33 & 79761703 & JZ896973 & XM_002517578.1 & Ricinus communis & 78.79 & DNA binding protein, putative & $2 \times 10^{-140}$ \\
\hline НВОН36 & 79761705 & JZ896975 & XM_002527643.1 & Ricinus communis & 84.82 & transcription factor btf 3 , putative & \\
\hline HBOH55 & 79761724 & JZ896994 & XM_002524212.1 & Ricinus communis & 82.11 & rop guanine nucleotide exchange factor, putative & 0 \\
\hline HBOH60 & 79761727 & JZ896997 & XM_006368449.1 & Populus trichocarpa & 85.21 & WRKY transcription factor 40 family protein & $4 \times 10^{-140}$ \\
\hline \multicolumn{8}{|c|}{ ESTs involved in transporter } \\
\hline $\mathrm{HBOH} 8$ & 79640388 & JZ822686 & XM_002521455.1 & Ricinus communis & 85.71 & dimethyladenosine transferase, putative & $1 \times 10^{-53}$ \\
\hline HBOH28 & 79761698 & JZ896968 & XM_002527741.1 & Ricinus communis & 88.11 & clathrin assembly protein, putative & $2 \times 10^{-144}$ \\
\hline НВOH38 & 79761707 & JZ896977 & XM_002529119.1 & Ricinus communis & 82.69 & DNA-directed RNA polymerase II, putative & $6 \times 10^{-154}$ \\
\hline НВOH39 & 79761708 & JZ896977 & XM_002529119.1 & Ricinus communis & 83.15 & DNA-directed RNA polymerase II, putative & $3 \times 10^{-158}$ \\
\hline НBOH44 & 79761713 & JZ896983 & XM_002269429.2 & Vitis vinifera & 66 & clathrin light chain 2 & $5 \times 10^{-73}$ \\
\hline HBOH46 & 79761715 & JZ896985 & XM_002531006.1 & Ricinus communis & 76.31 & transferase, transferring glycosyl groups, putative & $4 \times 10^{-90}$ \\
\hline HBOH52 & 79761721 & JZ896991 & HM461981.1 & Vernicia fordii & 84.48 & glycerol-3-phosphate acyltransferase 9 (GPAT9) gene & 0.00003 \\
\hline HBOH54 & 79761723 & JZ896993 & HQ285842.1 & Hevea brasiliensis & 98.95 & $\begin{array}{l}\text { chloroplast, complete genome }\end{array}$ & \\
\hline HBOH75 & 79761741 & JZ897011 & XM_002524326.1 & Ricinus communis & 72.5 & flavonol 4'-sulfotransferase, putative & $4 \times 10^{-51}$ \\
\hline HBOH81 & 79761747 & JZ897017 & XM_007017019.1 & Theobroma cacao & 72.69 & non-specific lipid-transfer protein, putative & $2 \times 10^{-26}$ \\
\hline \multicolumn{8}{|c|}{ ESTs involved in signal transduction } \\
\hline HBOH1 & 79640383 & JZ822681 & XM_002516001.1 & Ricinus communis & 68.49 & serine-threonine protein kinase, plant-type, putative & $4 \times 10^{-63}$ \\
\hline HBOH6 & 79640386 & JZ822684 & XM_002324361.2 & Populus trichocarpa & 87.66 & $\mathrm{H}^{+}$-ATPase family protein mRNA, complete cds & $2 \times 10^{-130}$ \\
\hline $\mathrm{HBOH} 9$ & 79721591 & JZ893120 & XM_003605902.1 & Medicago truncatula & 40 & hypothetical protein mRNA, complete cds & 0.0001 \\
\hline HBOH10 & 79640389 & JZ822687 & XM_007019829.1 & Theobroma cacao & 86.79 & cysteine-rich RLK (RECEPTOR-like protein kinase) 8 & 0.00002 \\
\hline HBOH22 & 79761693 & JZ896963 & XM_002514747.1 & Ricinus communis & 87.7 & 4-nitrophenylphosphatase, putative & \\
\hline HBOH23 & 79761694 & JZ896964 & XM_007019349.1 & Theobroma cacao & 66 & cysteine-rich RLK (RECEPTOR-like protein kinase) 8 & $5 \times 10^{-43}$ \\
\hline НВOH26 & 79761697 & JZ896967 & XM_002509773.1 & Ricinus communis & 83.05 & ATP binding protein, putative & $3 \times 10^{-170}$ \\
\hline НВOH41 & 79761710 & JZ896980 & XM_002308527.2 & Populus trichocarpa & 71.47 & kinase family protein & $9 \times 10^{-35}$ \\
\hline НBOH42 & 79761711 & JZ896981 & AM478326.2 & Vitis vinifera & 84.55 & contig VV78X154662.12, whole genome shotgun sequence & $5 \times 10^{-24}$ \\
\hline НBOH45 & 79761714 & JZ896984 & XM_007026459.1 & Theobroma cacao & 95.35 & signal transducer and transcription activator isoform 1 & $1 \times 10^{-28}$ \\
\hline HBOH53 & 79761722 & JZ896992 & XM_002524179.1 & Ricinus communis & 75.7 & kinase, putative & $3 \times 10^{-10}$ \\
\hline HBOH56 & 79761725 & JZ896995 & XM_002524179.1 & Ricinus communis & 75.26 & kinase, putative & $6 \times 10^{-47}$ \\
\hline
\end{tabular}


Table 1. Cont.

\begin{tabular}{|c|c|c|c|c|c|c|c|}
\hline ESTs & dbEST_Id & Accession No & Homology Found with & Homologous Species & Identity \% & Description & $E$-Value \\
\hline HBOH73 & 79761739 & JZ897009 & XM_002531397.1 & Ricinus communis & 83.52 & serine-threonine protein kinase, plant-type, putative & $1 \times 10^{-74}$ \\
\hline HBOH74 & 79761740 & JZ897010 & XM_002523439.1 & Ricinus communis & 82.36 & serine-threonine protein kinase, plant-type, putative & $5 \times 10^{-139}$ \\
\hline HBOH78 & 79761744 & JZ897014 & XM_002530595.1 & Ricinus communis & 69.87 & B-Raf proto-oncogene serine/threonine-protein kinase, putative & $9 \times 10^{-27}$ \\
\hline $\mathrm{HBOH} 80$ & 79761746 & JZ897016 & XM_002513521.1 & Ricinus communis & 88.85 & kinase, putative & $3 \times 10^{-107}$ \\
\hline \multicolumn{8}{|c|}{ ESTs involved in phytoalexin biosynthesis } \\
\hline HBOH48 & 79761717 & JZ896987 & DQ371802.1 & Populus alba & 83.36 & chalcone synthase (CHS) gene, CHS-M2 allele & $5 \times 10^{-159}$ \\
\hline HBOH61 & 79761728 & JZ896998 & XM_002300417.2 & Populus trichocarpa & 78.07 & senescence-related gene 1 family protein & $5 \times 10^{-180}$ \\
\hline HBOH62 & 79761729 & JZ896999 & XM_002517028.1 & Ricinus communis & 85.4 & acireductone dioxygenase, putative & $6 \times 10^{-35}$ \\
\hline HBOH63 & 79761730 & JZ897000 & XM_002519376.1 & Ricinus communis & 84.65 & UDP-glucosyltransferase, putative & \\
\hline HBOH70 & 79761737 & JZ897007 & XM_002533589.1 & Ricinus communis & 83.4 & leucoanthocyanidin dioxygenase, putative & 0 \\
\hline HBOH72 & 79761738 & JZ897008 & XM_002524028.1 & Ricinus communis & 76.42 & short chain alcohol dehydrogenase, putative & $4 \times 10^{-98}$ \\
\hline HBOH76 & 79761742 & JZ897012 & AY207387.1 & Hevea brasiliensis & 98.12 & 1-aminocyclopropane-1-carboxylate oxidase & $5 \times 10^{-98}$ \\
\hline HBOH77 & 79761743 & JZ897013 & XM_012216610.1 & Jatropha curcas & 99 & cytochrome P450 82C4-like (LOC105633910), mRNA & $1 \times 10^{-61}$ \\
\hline HBOH79 & 79761745 & JZ897015 & XM_002311738.2 & Populus trichocarpa & 84.97 & galactinol synthase family protein & \\
\hline HBOH83 & 79761749 & JZ897019 & XM_002531145.1 & Ricinus communis & 81.68 & geranyl geranyl pyrophosphate synthase, putative & $2 \times 10^{-146}$ \\
\hline HBOH85 & 79761751 & JZ897021 & XM_002531048.1 & Ricinus communis & 100 & cytochrome $\mathrm{P} 450$, putative, mRNA & $1 \times 10^{-81}$ \\
\hline \multicolumn{8}{|c|}{ ESTs involved in other metabolism } \\
\hline HBOH11 & 79640390 & JZ822688 & XM 002512371.1 & Ricinus communis & 77.2 & histone $\mathrm{h} 2 \mathrm{a}$, putative & $3 \times 10^{-59}$ \\
\hline HBOH12 & 79640391 & JZ822689 & XM_002297827.2 & Populus trichocarpa & 84.94 & Humj 1 family protein & $2 \times 10^{-124}$ \\
\hline HBOH18 & 79761690 & JZ896960 & HM363448.1 & Hevea brasiliensis & 94.58 & $60 S$ ribosomal protein L27B (RPL27B) & $3 \times 10^{-143}$ \\
\hline HBOH19 & 79761691 & JZ896961 & XM_007008726.1 & Theobroma cacao & 85.13 & ubiquitin-specific protease 24 isoform 4 & $1 \times 10^{-53}$ \\
\hline HBOH29 & 79761699 & JZ896969 & XM_002519479.1 & Ricinus communis & 71.98 & ribonucleoprotein, chloroplast, putative & $8 \times 10^{-28}$ \\
\hline НВОН30 & 79761700 & JZ896970 & КС533451.1 & Jatropha curcas & 70.7 & SCAR marker SCAR27-740-NT genomic sequence & $3 \times 10^{-16}$ \\
\hline HBOH32 & 79761702 & JZ896972 & XM_003540551.2 & Glycine max & 76.5 & RNA-binding protein 24 -like & $3 \times 10^{-59}$ \\
\hline HBOH40 & 79761709 & JZ896979 & XM_002520681.1 & Ricinus communis & 85.64 & photosystem I reaction center subunit II, chloroplast precursor, putative & \\
\hline НBOH47 & 79761716 & JZ896986 & AY247789.1 & Hevea brasiliensis & 72.73 & HEV2.1 gene & $1 \times 10^{-31}$ \\
\hline НBOH49 & 79761718 & JZ896988 & XM_002512371.1 & Ricinus communis & 80.46 & histone $\mathrm{h} 2 \mathrm{a}$, putative & $7 \times 10^{-68}$ \\
\hline HBOH57 & 79761726 & JZ896996 & M60274.1HEVRBSS & Hevea brasiliensis & 100 & ribulose-1,5-bisphosphate carboxylase small subunit (RbsS) & $7 \times 10^{-89}$ \\
\hline HBOH64 & 79761731 & JZ897001 & HQ285842.1 & Hevea brasiliensis & 100 & chloroplast, complete genome & $3 \times 10^{-171}$ \\
\hline $\mathrm{HBOH} 84$ & 79761750 & JZ897020 & HG975448.1 & Solanum pennellii & 82.22 & chromosome ch09, complete genome & $4 \times 10^{-28}$ \\
\hline \multicolumn{8}{|c|}{ Unclear ESTs } \\
\hline HBOH17 & 79761689 & JZ896959 & XM_002321005.2 & Populus trichocarpa & 73.09 & hypothetical protein & $2 \times 10^{-24}$ \\
\hline HBOH21 & 79761692 & JZ896962 & XM_002529035.1 & Ricinus communis & 84.38 & conserved hypothetical protein & $3 \times 10^{-107}$ \\
\hline HBOH24 & 79761695 & JZ896965 & XM_002514837.1 & Ricinus communis & 73.53 & conserved hypothetical protein & $6 \times 10^{-90}$ \\
\hline HBOH25 & 79761696 & JZ896966 & СТ028466.1 & Poplar & 78.79 & cDNA sequences & $7 \times 10^{-24}$ \\
\hline HBOH35 & 79761704 & JZ896974 & FN552731.1 & Hevea brasiliensis & 90 & microsatellite DNA, clone mHbCIRA2697 & $2 \times 10^{-51}$ \\
\hline HBOH37 & 79761706 & JZ896976 & XM_002519498.1 & Ricinus communis & 82.3 & $\begin{array}{l}\text { conserved hypothetical protein } \\
\text {. }\end{array}$ & 0 \\
\hline HBOH43 & 79761712 & JZ896982 & HQ285842.1 & Hevea brasiliensis & 99.72 & chloroplast, complete genome & 0 \\
\hline HBOH50 & 79761719 & JZ896989 & XM_002517090.1 & Ricinus communis & 86.52 & protein FRIGIDA, putative & $3 \times 10^{-168}$ \\
\hline HBOH51 & 79761720 & JZ896990 & EF146205.1 & Populus trichocarpa & 69.32 & clone WS0116_D21 unknown mRNA & $2 \times 10^{-12}$ \\
\hline HBOH65 & 79761732 & JZ897002 & AY439300.1 & Hevea brasiliensis & 83.91 & clone $\mathrm{hmct} 18$ microsatellite sequence & $2 \times 10^{-15}$ \\
\hline HBOH69 & 79761736 & JZ897006 & XM_002519826.1 & Ricinus communis & 87.7 & conserved hypothetical protein & $2 \times 10^{-106}$ \\
\hline HBOH82 & 79761748 & JZ897018 & AC213413.1 & Populus trichocarpa & 79.66 & clone POP014-E15, complete sequence & $7 \times 10^{-19}$ \\
\hline
\end{tabular}




\subsection{Analysis of Selected EST Gene Expression Profiles in RRIC52 and Reyan 7-33-97 after Powdery Mildew} Infection Using qRT-PCR

To understand the interaction between rubber tree and powdery mildew, we selected the first 15 ESTs (HBOH1-15) and analyzed their gene expression profiles in both the resistant RRIC52 and the mildly susceptible Reyan 7-33-97 using qRT-PCR. The leaves were harvested at 0, 12, 24, 72 and $120 \mathrm{~h}$ after powdery mildew infection, with three independent biological replicates at each time point. The gene expression in the inoculated plants was compared to that in the uninoculated plants of same developmental stages. Our results indicated that the expression of $\mathrm{HBOH} 1,2,6,8,10,11,12$ ESTs less than doubled (data not shown). On the other hand, the results (Figure 4) showed that the expression levels of eight ESTs (HBOH 3, 4, 5, 7, 9, 13, 14, 15) were highly upregulated during the course of powdery mildew infection compared to the uninoculated control plants. However, the expression patterns of these eight ESTs greatly varied between RRIC52 and Reyan 7-33-97.

$\mathrm{HBOH} 3, \mathrm{HBOH} 14$, and HBOH15 were upregulated in both RRIC52 and Reyan 7-33-97, but the expression levels peaked at different times post infection. Our results showed that the upregulation of $\mathrm{HBOH} 3, \mathrm{HBOH} 14$, and HBOH15 expressions peaked at $72 \mathrm{hpi}$ and then dropped in RRIC52 (Figure 4). However, the expression of these genes peaked at the later 120 hpi in Reyan 7-33-97, indicating a slower response of these genes in the susceptible cultivar. $\mathrm{HBOH} 3$ was predicted to be class 1 chitinase, catalyzing the hydrolysis of chitin polymers on a fungal cell wall. The expression of $\mathrm{HBOH} 3$ increased to 74.0-fold at $72 \mathrm{hpi}$ in RRIC52, and to 84.7-fold at $120 \mathrm{hpi}$ in Reyan 7-33-97. HBOH14 was predicted to be WRKY transcription factor, involved in the regulation of the immune effector process. The expression level of HBOH14 reached the highest of 94.6-fold at 72 hpi in RRIC52, and 213.5-fold at 120 hpi in Reyan 7-33-97. HBOH15 was predicted to be a germin-like protein, involved in plant cell wall reinforcement and papillae formation. Its expression level reached a peak of 58.3-fold at $72 \mathrm{hpi}$ in the resistant RRIC52. In the mildly susceptible Reyan 7-33-97, the HBOH15 expression level peaked at 3657.3-fold. Another upregulated gene was HBOH9 (a hypothetical protein). In both rubber tree cultivars, it showed the same expression pattern. At $120 \mathrm{hpi}$, the expression levels of $\mathrm{HBOH} 9$ peaked at 5.0-fold in RRIC52 and 53.3-fold in Reyan 7-33-97.

$\mathrm{HBOH} 5$ and HBOH13 were both upregulated in RRIC52. The expression levels of HBOH5 (predicted to be chitin elicitor receptor kinase) reached a maximum at 120 hpi to 3.2-fold and HBOH13 (a WRKY transcription factor) reached a maximum at 72 hpi to 5.8-fold in RRIC52. In Reyan7-33-97, the expression level of HBOH5 decreased by 1.13-fold at $12 \mathrm{hpi}$, but then increased and reached a maximum at 120 hpi of 3.9-fold. The expression level of HBOH13 was first downregulated and then upregulated to 3.5 -fold at $120 \mathrm{hpi}$.

$\mathrm{HBOH} 4$ was identified as a ferritin gene, regulating cellular iron under oxidative stress. Its expression level decreased 2.2-fold at $12 \mathrm{hpi}$, but went up to 2.5-fold at $72 \mathrm{hpi}$ in RRIC52. In Reyan7-33-97, it increased 16.4-fold at 120 hpi. HBOH7 was upregulated in Reyan 7-33-97 but not in RRIC52. HBOH7 was predicted to be putative glucan endo-1,3- $\beta$-glucosidase precursor. Its expression was 5.7-fold downregulated at $120 \mathrm{hpi}$ compared to $0 \mathrm{hpi}$ in the resistant RRIC52. However, its expression level in the mildly susceptible Reyan 7-33-97 continued to increase as infection progressed and it reached 84.7-fold at 120 hpi. 

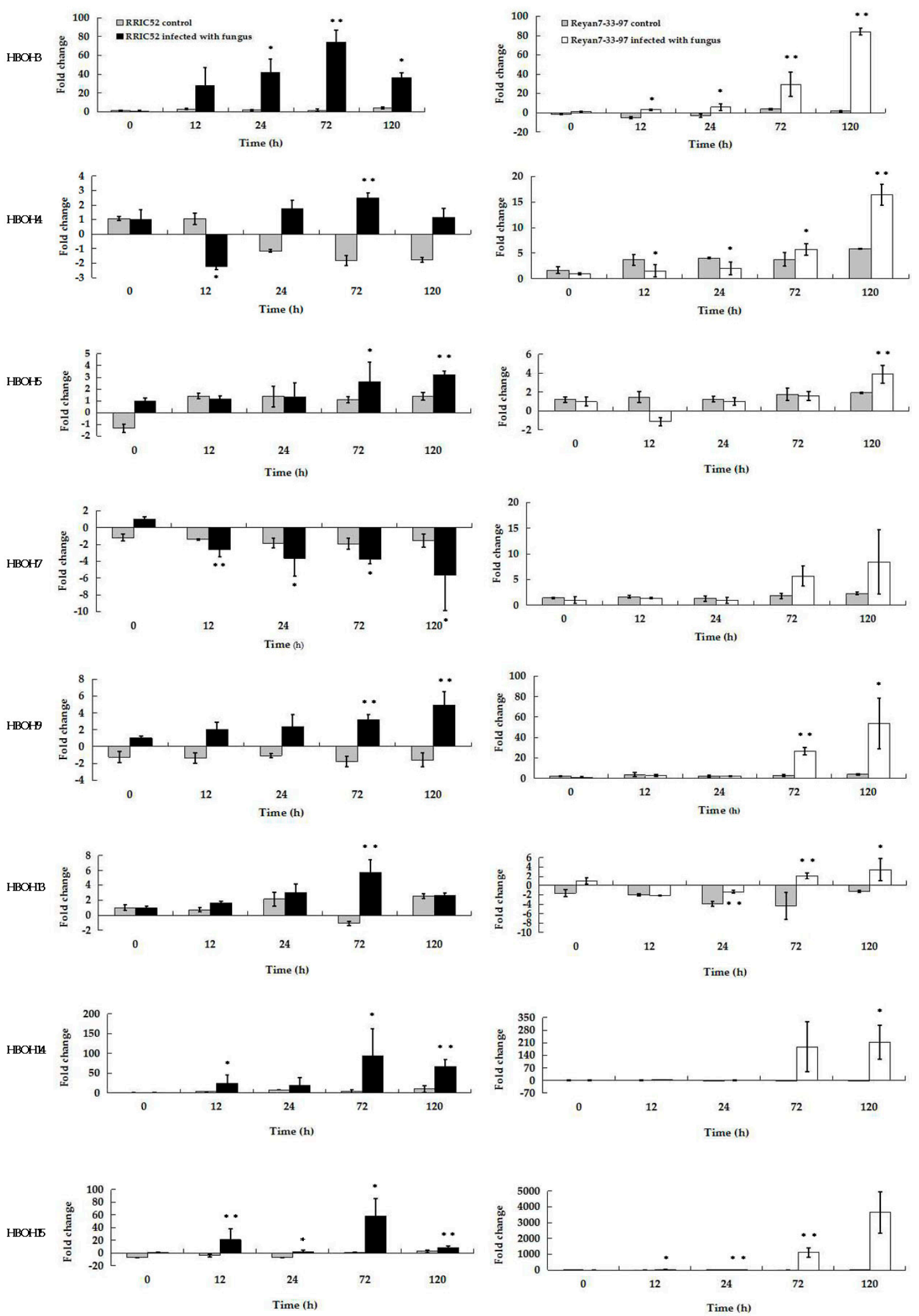

Figure 4. qRT-PCR analysis of eight EST expression levels in RRIC52 and Reyan 7-33-97 leaves during powdery mildew infection. Leaf samples were collected at $0,12,24,72$ and 120 hpi. Each gene expression level during the course of infection was compared to that at 0 hpi by the Pfaffl method [10], using RH8 and YLS8 in rubber tree as the reference genes; leaf samples from uninoculated plants of the same age were used as controls for each time point. Three biological replicates per cultivar were averaged and statistically analyzed using Student's $t$-test $\left({ }^{*}\right.$ indicates $\left.p<0.05 .{ }^{* *}, p<0.01\right)$ between control and powdery mildew-inoculated leaves. Bars indicate \pm S.E. from the results of three biological replicates. 
Table 2. Sequence homology of differential display-PCR clones to sequences in the GenBank database.

\begin{tabular}{|c|c|c|c|c|c|}
\hline Clone_ID & $\begin{array}{l}\text { Primer Pair Used } \\
\text { in DDRT-PCR }\end{array}$ & $\begin{array}{l}\text { Size } \\
\text { (bp) }\end{array}$ & $\begin{array}{l}\text { Similar Genes Found } \\
\text { in the Database }\end{array}$ & Functional Relevance & $\begin{array}{c}\text { Plant Defense } \\
\text { Mechanism Strategies }\end{array}$ \\
\hline $\mathrm{HBOH} 3$ & T11A/B0308 & 759 & $\begin{array}{l}\text { endochitinase } \\
\text { (Castanea sativa) }\end{array}$ & $\begin{array}{l}\text { Chitinases are enzymes that catalyze } \\
\text { the hydrolysis of the } \\
\text { beta- } 1,4-N \text {-acetyl-D-glucosamine } \\
\text { linkages in chitin polymers }\end{array}$ & $\begin{array}{l}\text { catalyzes the hydrolysis } \\
\text { of chitin polymers on } \\
\text { fungal cell wall }\end{array}$ \\
\hline $\mathrm{HBOH} 4$ & T11G/B0314 & 685 & $\begin{array}{l}\text { ferritin, plant, putative, } \\
\text { mRNA (Ricinus communis) }\end{array}$ & iron ion binding & $\begin{array}{l}\text { regulation of cellular iron } \\
\text { under oxidative stress }\end{array}$ \\
\hline HBOH7 & T11C/B0304 & 494 & $\begin{array}{l}\text { Glucan } \\
\text { endo-1,3- } \beta \text {-glucosidase } \\
\text { precursor, putative } \\
\text { (Ricinus communis) }\end{array}$ & involved in carbohydrate binding & $\begin{array}{l}\text { hydrolyses } \beta-1,3 \text { gucans } \\
\text { on fungal cell wall }\end{array}$ \\
\hline НBOH13 & T11C/B0322 & 525 & $\begin{array}{l}\text { WRKY transcription factor } \\
40 \text { family protein } \\
\text { (Populus trichocarpa })\end{array}$ & $\begin{array}{l}\text { involved in the regulation of various } \\
\text { physiological programs that are unique } \\
\text { to plants, including pathogen defense, } \\
\text { senescence and trichome development }\end{array}$ & $\begin{array}{l}\text { regulation of immune } \\
\text { effector process }\end{array}$ \\
\hline $\mathrm{HBOH} 14$ & T11G/B0308 & 251 & $\begin{array}{l}\text { WRKY transcription } \\
\text { factor } 18 \text {-like } \\
\text { (Gossypium raimondii) }\end{array}$ & $\begin{array}{l}\text { involved in the regulation of various } \\
\text { physiological programs that are unique } \\
\text { to plants, including pathogen defense, } \\
\text { senescence and trichome development }\end{array}$ & $\begin{array}{l}\text { regulation of immune } \\
\text { effector process }\end{array}$ \\
\hline НBOH15 & T11A/AP34 & 305 & $\begin{array}{l}\text { germin-like protein } 1 \\
\text { (Populus trichocarpa) }\end{array}$ & $\begin{array}{l}\text { involved in plant cell wall } \\
\text { reinforcement and papillae formation }\end{array}$ & $\begin{array}{l}\text { protected epidermal cells } \\
\text { from attack by fungus }\end{array}$ \\
\hline
\end{tabular}

\section{Discussion}

Plants defend themselves against pathogen infection through a variety of mechanisms at different stages during the pathogen infection. Of the powdery mildew resistance mechanisms that have been extensively studied, the barley mlo confers effective broad-spectrum resistance against all known isolates of Blumeria graminis f.sp. hordei (Bgh) [11]. The Run1 (Resistance to Uncinula necator 1) [12,13] and Ren1 (Resistance to Erysiphe necator 1) [14,15] are two grape loci associated with powdery mildew resistance. In Arabidopsis, the $\mathrm{R}$ gene-mediated defense came from the isolation and functional characterization of RPW8 conferring broad spectrum resistance to powdery mildew pathogens [16]. However, up to now, there have been very few studies on the rubber tree defensive mechanisms to $O$. heveae powdery mildew infection.

In this study, we used the DDRT-PCR method to identify genes that were differentially expressed in rubber tree resistant cultivar RRIC52 at five crucial stages during the powdery mildew infection. These five stages were identified as: (i) $0 \mathrm{~h}$ without infection as control; (ii) the $12 \mathrm{hpi}$ stage with the primary haustoria formation reaching its peak; (iii) the 24 hpi stage with the pathogen forming hyphae from conidiospores; (iv) the $72 \mathrm{hpi} \mathrm{stage} \mathrm{with} \mathrm{hyphae} \mathrm{expanding} \mathrm{on} \mathrm{the} \mathrm{leaf} \mathrm{surface;} \mathrm{and} \mathrm{(v)} \mathrm{the} 120 \mathrm{hpi}$ stage with lesion formation and fungal sporulation. Our results showed that at least 78 expressed sequence tags (ESTs) exhibited differentially regulated expressions in the interaction between rubber tree and $O$. heveae powdery mildew. The differences in the expression of several genes were analyzed by qRT-PCR and compared between the resistant RRIC52 and the susceptible Reyan 7-33-97 cultivars. This study improved our understanding of the gene network that regulates the interaction between O. heveae powdery mildew and rubber trees.

\subsection{Cell Wall Pathway and PR Protein}

Plant cell walls provide a physical barrier to pathogens. Plant cells have many mechanisms responding to cell wall damage. Germins and germin-like proteins (GLPs) are plant cell wall 
glycoproteins, classified into an exclusive cupin subfamily [17]. GLPs have been implicated in plant cell wall reinforcement and papillae formation during pathogen attack [18-21]. HBOH15 identified in our study matched to a germin-like protein in P. trichocarpa. Our data showed that its expression was upregulated $>3000$-fold in the mildly susceptible Reyan 7-33-97. It has been previously reported that several GLP subfamilies were strongly induced during Blumeria graminis f. sp. hordei infection, and the transient overexpression of GLPs protected barley epidermal cells from attack by the appropriate powdery mildew fungus [22]. $V v G L P 3$, a GLP gene in grapevines, was induced specifically by E. necator infection, and involved in the defense response against this powdery mildew [23].

In addition, many fungi are thought to produce cell-wall-degrading enzymes in order to breach the host cell wall. Plants combat fungal infections by synthesis of a number of pathogenesis-related (PR) proteins [24]. One such example is $\beta$-1,3-glucanase. HBOH7 was found to be similar with the genes coding for $\beta$-1,3-glucanase in Populus trichocarpa. $\beta$-1,3-glucanase hydrolyzes $\beta$-glucans, which is a major component of fungal cell walls [25]. Another example is chitinase, an enzyme that catalyzes the hydrolysis of chitin polymers in the cell walls of invading fungal hyphae [26]. In our study the sequences of two DD-obtained transcripts, $\mathrm{HBOH} 3$ and $\mathrm{HBOH} 5$, were found to be similar to the genes coding for endochitinase of Castanea sativa and chitin elicitor receptor kinase 1 of Arabidopsis thaliana, respectively. Previous studies reported that both chitinase and $\beta-1,3$-glucanase activity were increased in grapevines against the powdery mildew fungus $U$. necator [27]. Our results showed these two ESTs were induced in both RRIC52 and Reyan 7-33-97 cultivars.

\subsection{Transcription Factor}

Chitin elicitation appears to play a significant role in plant defense to fungal pathogens. Chitin-responsive transcription factor genes likely represent key elements in the ability of chitin to modify gene expression as part of the plant defense reaction. It has been reported that there were 14 WRKY genes significantly upregulated after chitin treatment in Arabidopsis [28]. WRKY factors are key regulators in modulating the expression of genes involved in plant defense response pathway [29]. In our study, $\mathrm{HBOH} 13$ and $\mathrm{HBOH} 14$ were induced upon infection with the powdery mildew during early stages of infection. They were identified as WRKY18 and WRKY40, respectively. WRKY18 and WRKY40 are thought to negatively regulate resistance towards the biotrophic powdery mildew fungus Golovinomyces orontii [30,31]. In barley, the transcriptional knockdown of HvWRKY1 HvWRKY2 that share the highest homology to Arabidopsis WRKY18 and WRKY40 results in an increased resistance against Blumeria graminis f. sp. hordei (Bgh) [32].

\subsection{Transporter}

Endocytosis in plants has an essential role not only for basic cellular functions but also for pathogen defense. The major endocytic mechanism in plants is clathrin-mediated endocytosis [33]. This study identified two ESTs, HBOH28 (similar to clathrin assembly protein) and HBOH44 (similar to clathrin light chain), that may participate in this pathway. $\mathrm{HBOH} 55$ was identified as being among the guanine nucleotide exchange factors (GEFs) that are known to be required for endocytosis and play a role in clathrin-dependent endocytosis in plants [34].

Plant lipid transfer proteins (LTPs) targeted to epidermal cell walls [35] are reported to be induced in response to pathogen infection and are included as PR-proteins [36]. HBOH81 was identified as a lipid-transfer protein gene. When an LTP (Ace-AMP1) isolated from Allium cepa was introduced into wheat plants, it enhanced transgenic wheat plants' resistance to powdery mildew Blumeria graminis $\mathrm{f}$. sp. tritici [37]. When the same gene was transplanted into roses, it also conferred resistance to powdery mildew Sphaerotheca pannosa [38].

\subsection{Signal Transduction}

ESTs involved in signal transduction pathways included some plant protein kinases. Certain protein kinases were likely to be crucially associated with plant immune responses. Our study showed 
that a few protein kinases were induced by powdery mildew in rubber tree: $\mathrm{HBOH} 41, \mathrm{HBOH} 53$, $\mathrm{HBOH} 56$, and $\mathrm{HBOH} 80$, which were identified as protein kinases. $\mathrm{HBOH} 1, \mathrm{HBOH} 42, \mathrm{HBOH} 73$, $\mathrm{HBOH} 74$, and $\mathrm{HBOH} 78$ were similar to serine-threonine protein kinase, and $\mathrm{HBOH} 45$ was identified as a signal transducer and transcription activator.

Previous study has shown that a putative serine and threonine protein kinase gene from $H$. villosa (Stpk-V) was significantly upregulated by Bgt (Blumeria graminis f. sp. tritici). The transformation of Stpk-V into a susceptible wheat variety conferred high and broad-spectrum resistance to powdery mildew [39]. The Pto kinase contained similar domains as serine/threonine (S/T) kinases, conferred resistance to bacterial-speck disease in tomato plants [40]. Protein kinases are also involved in the development of HR, SAR, and the SA-mediated induction of PR-1 gene expression in tobacco [41].

\subsection{Phytoalexin Biosynthesis}

Plants respond to pathogen attacks by the synthesis of not only pathogenesis-related (PR) proteins, such as glucanases and chitinases, but also antimicrobial compounds, such as phytoalexins [42]. Phytoalexin biosynthesis genes were identified in our study, indicating the importance of phytoalexins in the defense response of rubber tree to powdery mildew infection. The phenylpropanoid pathway is central in the plant defense response [43]. HBOH48 encodes a chalcone synthase (CHS) gene. CHS is a key enzyme in the phenylpropanoid pathway; its enhanced expression indicates the activation of the resistant response [44]. CHS can induce plants to produce more flavonoids and other related metabolites against stress [45]. Flavonoid-type phytoalexins are important in protecting plants from various phytopathogens and stress [46,47], and preformed flavonoids in host-pathogen interactions may play a direct signaling role in defense [48]. In our study, four ESTs (HBOH48, HBOH61, HBOH63, and $\mathrm{HBOH} 70$ ) were found to be involved in the flavonoid biosynthetic pathway.

Two cytochrome P450s ESTs (HBOH77, HBOH85) were identified in our study. Cytochrome P450s, a family of hemoproteins, play a prominent role in plant defense as they are instrumental in the biosynthesis of terpenoid, lignins, alkaloids, and a variety of other secondary components that are common defense agents [49-51]. A novel cytochrome P450, CaCYP1, was isolated in pepper plants and shown to play a potential role in plant defense response pathways that involve ABA- and SA-mediated signaling mechanisms [52]. A Phytophthora infestans-induced cytochrome P450 gene was potentially associated with quantitative resistance to potato late blight disease [43]. In Arabidopsis, cytochrome P450 genes were shown to be upregulated after inoculation with A. brassicicola and A. alternata [53].

\subsection{ESTs Involved in Other Metabolic Pathways}

$\mathrm{HBOH} 4$ was shown to share high homology with ferritins. Its expression reached the highest level at $72 \mathrm{hpi}$ in the resistant RRIC52. It has been reported that ferritin enhanced tolerance to ROS (reactive oxygen species) and necrosis caused by viral and fungal infections in tobacco [54]. The Arabidopsis $28 \mathrm{kDa}$ ferritin plays a main role in the regulation of cellular iron under oxidative stress in Brasicca juncea [55,56]. An oxidative burst is known to be one of the earliest events that take place in plants under stress [57].

Up to now, there have been very few studies on the resistance genes in rubber tree against powdery mildew infection, and the rubber tree's defensive mechanisms to powdery mildew remain unclear. Qin et al. reported the cloning of an Mlo gene in a rubber tree in 2015 [3]. However, the Mlo gene expression did not change significantly during powdery mildew infection. Our DDRT-PCR analysis is the first to reveal the complex pattern of differential gene expression in the rubber tree during $O$. heveae powdery mildew infection. The identified $H$. brasiliensis genes involved in the infection process of $O$. heveae should provide a useful reference for developing new strategies to improve the resistance of rubber tree to powdery mildew disease. 


\section{Materials and Methods}

\subsection{Rubber Trees and O. heveae}

The highly resistant rubber tree cultivar RRIC52 and the mildly susceptible cultivar Reyan 7-33-97 were both grown in plastic pots in the greenhouse at the experimental farm of Hainan University, Haikou, China. They were two-year-old grafted plants kept in the greenhouse until their leaves reached the suitable developmental stage for inoculation.

The powdery mildew pathogen $O$. heveae isolate $\mathrm{HO}-73$ was isolated from the experimental farm and maintained on small Reyan 7-33-97 grafted plants.

\subsection{Inoculation of Rubber Trees with O. heveae HO-73}

The infected leaves of Reyan 7-33-97 grafted plants were shaken $24 \mathrm{~h}$ before inoculation to allow the formation of fresh conidial spores. For inoculation, conidia were dusted from infector rubber tree leaves to the leaves of the two cultivars. Plants were incubated in a growth chamber at $21-22{ }^{\circ} \mathrm{C}$ with $60 \%-70 \%$ humidity and a $16 \mathrm{~h}$ photoperiod for $120 \mathrm{~h}$. Leaves from plants at different infection times $(0$, $12,24,72$ and $120 \mathrm{~h}$ ) were collected to analyze gene expression changes in response to powdery mildew infection. Leaf samples were also collected from uninoculated plants as controls. All samples were immediately frozen in liquid nitrogen and stored at $-80^{\circ} \mathrm{C}$ for total RNA extraction. Three biological replicates were used for all treatments.

Alcoholic trypan blue assay [58] was performed to analyze the O. heveae infection on tested plant leaves from RRIC52 and Reyan 7-33-97. The infected leaves were collected $120 \mathrm{~h}$ after inoculation. They were cleared for $10-60 \mathrm{~min}$ at $70{ }^{\circ} \mathrm{C}$ temperature in an ethanol-chloroform $(75: 25, v / v)$ mixture containing $0.15 \%$ trichloroacetic acid [59]. The leaf sections were stained with lactophenol-trypan blue (10 mL of lactic acid, $10 \mathrm{~mL}$ of glycerol, $10 \mathrm{~g}$ of phenol and $10 \mathrm{mg}$ of trypan blue, dissolved in $10 \mathrm{~mL}$ of distilled water) for $5 \mathrm{~min}$, and then examined under an Olympus BX-51 light microscope.

\subsection{RNA Extraction and cDNA Synthesis}

Total RNA was isolated from each leaf sample as described [60]. Genomic DNA was removed by DNase I digestion (RNase-free) (Thermo Scientific, Waltham, MA, USA). The RNA integrity was assessed by agarose gel electrophoresis. The concentration and quality of RNA were determined by the A260 absorbance and the A260/A280 ratio using a NanoDrop 2000 spectrophotometer (Thermo Scientific, Waltham, MA, USA). All RNA samples were adjusted to the same concentration in the subsequent reverse transcription reaction. Total RNA from powdery mildew-infected RRIC52 was used for DDRT-PCR. Total RNAs from powdery mildew-infected and control RRIC52 and Reyan7-33-97 plants were used for qRT-PCR.

\subsection{Differential Display Analysis}

mRNA differential display (DD) was performed essentially as previously described [61] with the total RNA of RRIC52. First-strand cDNA was synthesized using $2 \mu \mathrm{g}$ total RNA as template by the RevertAid ${ }^{\mathrm{TM}}$ First Strand cDNA Synthesis Kit (Fermentas, Waltham, MA, USA) according to the manufacturer's instruction. Three sets of anchored 3'-oligo (dT) primers (H-T11M, M = A/G/C) were used to synthesize first-strand cDNA. PCR amplification was performed using in combination with one reverse transcription step anchored primer and one arbitrary primer (B0301-B0326, Ap27-Ap34 in Supplementary Material, Table S4). The oligo (dT) primers and arbitrary primers were obtained from Sangon Biotech Corp (Shanghai, China). Each reaction mixture, in a total volume of $20 \mu \mathrm{L}$, contained $2 \mu \mathrm{L}$ first strand cDNA, $2 \mathrm{mM}$ each of dNTPs, $0.2 \mu \mathrm{M}$ of random primers, $0.2 \mu \mathrm{M}$ of anchored primer, and 1 unit of Taq DNA polymerase (Fermentas). The cycling parameters were as follows: $94^{\circ} \mathrm{C}$ for $30 \mathrm{~s}, 40{ }^{\circ} \mathrm{C}$ for $2 \mathrm{~min}, 72{ }^{\circ} \mathrm{C}$ for $30 \mathrm{~s}$ for 40 cycles followed by $72{ }^{\circ} \mathrm{C}$ for $5 \mathrm{~min}$. The amplified cDNAs were then separated on a $6 \%$ denaturing polyacrylamide gel. 


\subsection{Isolation of Differentially Displayed cDNA Bands from Agarose Gel}

Compared with the control sample at $0 \mathrm{~h}$, differentially expressed DNA bands were marked in

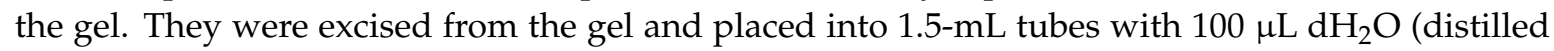
water). The tubes were placed in a boiling water bath for $10 \mathrm{~min}$. Each eluted DNA was used as the template for PCR re-amplification using the appropriate primer pairs. Successfully re-amplified cDNA fragments were electrophoresed on agarose gel and purified with a gel extraction kit (OMEGA, Norcross, GA, USA) and stored at $-20^{\circ} \mathrm{C}$ for reverse Northern analysis and subcloning.

\subsection{Reverse Northern Dot Blot, Cloning, and Sequence Analysis}

For the reverse Northern dot-blot analysis, the re-amplified and purified cDNAs (300 ng) were denatured with $0.1 \mathrm{M} \mathrm{NaOH}$ and neutralized with $0.1 \mathrm{M}$ Tris-HCl. Each $1-\mu \mathrm{L}$ sample was manually applied to one of five nylon membranes and baked for $30 \mathrm{~min}$ at $80^{\circ} \mathrm{C}[62,63]$. The cDNA pools of 0 , 12, 24, 72 and $120 \mathrm{~h}$ were respectively labeled with DIG (DIG High Prime DNA Labeling and Detection Starter Kit II, Roche, Basel, Switzerlan) as probes to hybridize with the membrane blotted with the purified DNA bands according to the manufacturer's instruction. An equal amount of each DIG-labeled cDNA mixture was denatured and separately hybridized to one of the five membranes according to the manufacturer's instructions. The expression level of each cDNA for a differentially expressed gene was obtained from the ratio of the inoculated sample versus the control after normalizing to the expression of $18 \mathrm{~S}$ rRNA.

After validation by DDRT-PCR, second round-PCR, and Reverse Northern dot blot analysis, the positive DNA bands were then cloned into a pMD19-T vector (Takara) and transformed into competent DH5 $\alpha$ cells (TransGen Biotech, Beijing, China). Positive recombinant clones identified by PCR amplification were sequenced by BGI Biotech Co., Ltd. (Beijing, China). DNA sequences were analyzed against the National Center for Biotechnology Information (NCBI, Bethesda, MD, USA) database using the BLAST tool. Rahman et al. [64] reported the whole genome of $\mathrm{H}$. brasiliensis clone RRIM 600 in the year 2013; we also have blasted (BLAST 2.2.29+) to analysis our 78 unique DD-derived ESTs in the presence genome.

\subsection{Expression Validation by Real-Time Quantitative RT-PCR}

qRT-PCR analyses were carried out to validate the putative differentially expressed genes that were likely involved in rubber tree defense mechanism against powdery mildew. PCR primers (Supplementary Material, Table S5) were designed using Primer 5.0 (Premier Biosoft International, Palo Alto, CA, USA). The gene expressions of two rubber tree cultivars that respond to powdery mildew differently were compared. We also have followed the expression of the candidate genes in both cultivars under control condition (no infection) during the whole time course.

The first-strand cDNA was synthesized from $2 \mu \mathrm{g}$ total RNA in a total volume of $20 \mu \mathrm{L}$ using the PrimeScript ${ }^{\mathrm{TM}}$ RT Reagent Kit (Takara). The PCR reaction was performed in a $10 \mu \mathrm{L}$ reaction mixture containing $1 \times$ SYBR Premix EX Taq (Takara), $0.2 \mu \mathrm{M}$ of each primer, and $15 \mathrm{ng}$ cDNA per sample. The PCR reactions were performed with the following program: $95^{\circ} \mathrm{C}$ for $30,95^{\circ} \mathrm{C}$ for $5 \mathrm{~s}$, $60^{\circ} \mathrm{C}$ for $20 \mathrm{~s}$. and $72{ }^{\circ} \mathrm{C}$ for $20 \mathrm{~s}$, for a total of 40 cycles in 384-well optical reaction plates with the CFX384 system (Bio-Rad Laboratories, Hercules, CA, USA). To validate all primers and amplifications, melting curves were examined for all qPCR products, and the amplification efficiency $(E)$ of each primer set and correlation coefficient $\left(R^{2}\right)$ were calculated using the standard curve method. Data analysis was calculated by the Pfaffl method [10]. The housekeeping genes RH8 and YLS8, which are stably expressed in the rubber tree [65], were both used as reference genes.

At least three independent biological replicates were performed for all the datasets. Each biological replicate was carried out in at least three technical replicates and the values were presented as mean \pm S.E. from the results of three biological replicates. Student's $t$-test $\left({ }^{*}\right.$ indicates $p<0.05$. $* *, p<0.01$ ) was used to determine the significant difference between the treatments. 


\section{Conclusions}

In this study, we showed for the first time the identification of the responsive genes during powdery mildew infection in the rubber tree. We demonstrated the similar or different gene expression changes of eight such responsive genes between two rubber tree cultivars with different resistance levels by qRT-PCR. These eight genes include three fungal cell wall hydrolysis enzymes, a ferritin protein, a single-pass membrane protein, two regulation immune effectors, and a germin-like protein. Our study has provided the much-needed information to understand the powdery mildew defense mechanisms in the rubber tree.

Supplementary Materials: Supplementary materials can be found at http://www.mdpi.com/1422-0067/ $17 / 2 / 181 /$ s1.

Acknowledgments: We thank the Rubber Research Institute, Chinese Academy of Tropical Agricultural Sciences for providing the RRIC52 plants. This work was supported by grants from the National Key Basic Research Plan of China (2011CB111612), the National Natural Science Foundation of China (31160359), and the National agricultural industrial technology system (CARS-34-GW8), as well as by research and start-up capital from Hainan University (kyqd1006).

Author Contributions: Weiguo Miao, Fucong Zheng and Xiang Li conceived and designed the experiments; Xiang Li and Zhenghong Bi performed the experiments; Xiang Li, Zhenghong Bi, and Peng Liang analyzed the data; Peng Liang, Qiguang He, and Wenbo Liu contributed fungal and Plant Reyan 7-33-97 materials; Xiang Li and Rong Di wrote and revised the paper.

Conflicts of Interest: The authors declare no conflict of interest.

\section{References}

1. Lertpanyasampatha, M.; Viboonjun, U.; Kongsawadworakul, P.; Chrestin, H.; Narangajavana, J. Differential expression of microRNAs and their targets reveals a possible dual role in physiological bark disorder in rubber tree. J. Plant Physiol. 2014, 171, 1117-1126. [CrossRef] [PubMed]

2. Li, D.; Deng, Z.; Chen, C.; Xia, Z.; Wu, M.; He, P.; Chen, S. Identification and characterization of genes associated with tapping panel dryness from hevea brasiliensis latex using suppression subtractive hybridization. BMC Plant Biol. 2010, 10, 140. [CrossRef] [PubMed]

3. Qin, B.; Zheng, F.; Zhang, Y. Molecular cloning and characterization of a Mlo gene in rubber tree (Hevea brasiliensis). J. Plant Physiol. 2015, 175, 78-85. [CrossRef] [PubMed]

4. Limkaisang, S.; Kom-un, S.; Furtado, E.L.; Liew, K.W.; Salleh, B.; Sato, Y.; Takamatsu, S. Molecular phylogenetic and morphological analyses of oidium heveae, a powdery mildew of rubber tree. Mycoscience 2005, 46, 220-226. [CrossRef]

5. Manickavelu, A.; Kawaura, K.; Oishi, K.; Shin, T.; Kohara, Y.; Yahiaoui, N.; Keller, B.; Suzuki, A.; Yano, K.; Ogihara, Y. Comparative gene expression analysis of susceptible and resistant near-isogenic lines in common wheat infected by Puccinia triticina. DNA Res. 2010, 17, 211-222. [CrossRef] [PubMed]

6. Liang, P.; Pardee, A.B. Differential display of eukaryotic messenger RNA by means of the polymerase chain reaction. Science 1992, 257, 967-971. [CrossRef] [PubMed]

7. Liang, P. A decade of differential display. Biotechniques 2002, 33, 338-347. [PubMed]

8. Ruiyi, Y.Z.W.S.F. Resistant behaviour of popular rubber clones in China to oidium heveae. Chin. J. Trop. Crops 1992, 1, 007.

9. EST database of GenBank. Available online: http://www.ncbi.nlm.nih.gov/biosample/?term= Library\% 20of $\% 20$ differentially $\% 2$ expressed $\% 20 \% 20 \% 20 \% 20 \% 20 \% 20 \% 20 \% 20 \% 20 \% 20 \% 20 \% 20 \% 20 \% 20 \% 20 \% 20 \% 20$ transcripts\%20in $\% 20$ Hevea\%20brasiliensis $\% 20$ clone $\% 20$ RRIC52\%20inoculated $\% 20 \% 20 \% 20 \% 20 \% 20 \% 20 \%$ $20 \% 20 \% 20 \% 20 \% 20 \% 20 \% 20 \% 20 \% 20 \% 20 \% 20$ with $\% 20$ powdery $\% 20$ mildew (accessed on 5 December 2015).

10. Pfaffl, M.W. A new mathematical model for relative quantification in real-time RT-PCR. Nucleic Acids Res. 2001, 29, e45. [CrossRef] [PubMed]

11. Elliott, C.; Zhou, F.; Spielmeyer, W.; Panstruga, R.; Schulze-Lefert, P. Functional conservation of wheat and rice Mlo orthologs in defense modulation to the powdery mildew fungus. Mol. Plant-Microbe Interact. 2002, 15, 1069-1077. [CrossRef] [PubMed] 
12. Barker, C.L.; Donald, T.; Pauquet, J.; Ratnaparkhe, M.; Bouquet, A.; Adam-Blondon, A.-F.; Thomas, M.; Dry, I. Genetic and physical mapping of the grapevine powdery mildew resistance gene, Run1, using a bacterial artificial chromosome library. Theor. Appl. Genet. 2005, 111, 370-377. [CrossRef] [PubMed]

13. Donald, T.; Pellerone, F.; Adam-Blondon, A.-F.; Bouquet, A.; Thomas, M.; Dry, I. Identification of resistance gene analogs linked to a powdery mildew resistance locus in grapevine. Theor. Appl. Genet. 2002, 104, 610-618. [CrossRef] [PubMed]

14. Coleman, C.; Copetti, D.; Cipriani, G.; Hoffmann, S.; Kozma, P.; Kovács, L.; Morgante, M.; Testolin, R.; di Gaspero, G. The powdery mildew resistance gene REN1 co-segregates with an NBS-LRR gene cluster in two central Asian grapevines. BMC Genet. 2009, 10, 89. [CrossRef] [PubMed]

15. Hoffmann, S.; di Gaspero, G.; Kovács, L.; Howard, S.; Kiss, E.; Galbács, Z.; Testolin, R.; Kozma, P. Resistance to Erysiphe necator in the grapevine "Kishmish vatkana" is controlled by a single locus through restriction of hyphal growth. Theor. Appl. Genet. 2008, 116, 427-438. [CrossRef] [PubMed]

16. Xiao, S.; Ellwood, S.; Calis, O.; Patrick, E.; Li, T.; Coleman, M.; Turner, J.G. Broad-spectrum mildew resistance in arabidopsis thaliana mediated by RPW8. Science 2001, 291, 118-120. [CrossRef] [PubMed]

17. Dunwell, J.M.; Khuri, S.; Gane, P.J. Microbial relatives of the seed storage proteins of higher plants: Conservation of structure and diversification of function during evolution of the cupin superfamily. Microbiol. Mol. Biol. Rev. 2000, 64, 153-179. [CrossRef] [PubMed]

18. Christensen, A.B.; Thordal-Christensen, H.; Zimmermann, G.; Gjetting, T.; Lyngkjær, M.F.; Dudler, R.; Schweizer, P. The germinlike protein GLP4 exhibits superoxide dismutase activity and is an important component of quantitative resistance in wheat and barley. Mol. Plant-Microbe Interact. 2004, 17, 109-117. [CrossRef] [PubMed]

19. Wei, Y.; Zhang, Z.; Andersen, C.H.; Schmelzer, E.; Gregersen, P.L.; Collinge, D.B.; Smedegaard-Petersen, V.; Thordal-Christensen, H. An epidermis/papilla-specific oxalate oxidase-like protein in the defence response of barley attacked by the powdery mildew fungus. Plant Mol. Biol. 1998, 36, 101-112. [CrossRef] [PubMed]

20. Gucciardo, S.; Wisniewski, J.-P.; Brewin, N.J.; Bornemann, S. A germin-like protein with superoxide dismutase activity in pea nodules with high protein sequence identity to a putative rhicadhesin receptor. J. Exp. Bot. 2007, 58, 1161-1171. [CrossRef] [PubMed]

21. Schweizer, P.; Christoffel, A.; Dudler, R. Transient expression of members of the germin-like gene family in epidermal cells of wheat confers disease resistance. Plant J. 1999, 20, 541-552. [CrossRef] [PubMed]

22. Zimmermann, G.; Bäumlein, H.; Mock, H.-P.; Himmelbach, A.; Schweizer, P. The multigene family encoding germin-like proteins of barley. Regulation and function in basal host resistance. Plant Physiol. 2006, 142, 181-192. [CrossRef] [PubMed]

23. Godfrey, D.; Able, A.J.; Dry, I.B. Induction of a grapevine germin-like protein (VvGLP3) gene is closely linked to the site of Erysiphe necator infection: A possible role in defense? Mol. Plant-Microbe Interact. 2007, 20, 1112-1125. [CrossRef] [PubMed]

24. Van Loon, L. Pathogenesis-related proteins. Plant Mol. Biol. 1985, 4, 111-116. [CrossRef] [PubMed]

25. Wolski, E.A.; Maldonado, S.; Daleo, G.R.; Andreu, A.B. A novel $\alpha$-1,3-glucan elicits plant defense responses in potato and induces protection against rhizoctonia solani AG-3 and Fusarium solani f. Sp. eumartii. Physiol. Mol. Plant Pathol. 2006, 69, 93-103. [CrossRef]

26. Shibuya, N.; Minami, E. Oligosaccharide signalling for defence responses in plant. Physiol. Mol. Plant Pathol. 2001, 59, 223-233. [CrossRef]

27. Giannakis, C.; Bucheli, C.; Skene, K.; Robinson, S.; Scott, N.S. Chitinase and $\beta$-1,3-glucanase in grapevine leaves: A possible defence against powdery mildew infection. Aust. J. Grape Wine Res. 1998, 4, 14-22. [CrossRef]

28. Libault, M.; Wan, J.; Czechowski, T.; Udvardi, M.; Stacey, G. Identification of 118 arabidopsis transcription factor and 30 ubiquitin-ligase genes responding to chitin, a plant-defense elicitor. Mol. Plant-Microbe Interact. 2007, 20, 900-911. [CrossRef] [PubMed]

29. Rushton, P.J.; Somssich, I.E.; Ringler, P.; Shen, Q.J. WRKY transcription factors. Trends Plant Sci. 2010, 15, 247-258. [CrossRef] [PubMed]

30. Pandey, S.P.; Roccaro, M.; Schön, M.; Logemann, E.; Somssich, I.E. Transcriptional reprogramming regulated by WRKY18 and WRKY40 facilitates powdery mildew infection of arabidopsis. Plant J. 2010, 64, 912-923. [CrossRef] [PubMed] 
31. Xu, X.; Chen, C.; Fan, B.; Chen, Z. Physical and functional interactions between pathogen-induced arabidopsis WRKY18, WRKY40, and WRKY60 transcription factors. Plant Cell 2006, 18, 1310-1326. [CrossRef] [PubMed]

32. Shen, Q.-H.; Saijo, Y.; Mauch, S.; Biskup, C.; Bieri, S.; Keller, B.; Seki, H.; Ülker, B.; Somssich, I.E.; Schulze-Lefert, P. Nuclear activity of MLA immune receptors links isolate-specific and basal disease-resistance responses. Science 2007, 315, 1098-1103. [CrossRef] [PubMed]

33. Šamaj, J.; Baluška, F.; Voigt, B.; Schlicht, M.; Volkmann, D.; Menzel, D. Endocytosis, actin cytoskeleton, and signaling. Plant Physiol. 2004, 135, 1150-1161. [CrossRef] [PubMed]

34. Chen, X.; Irani, N.G.; Friml, J. Clathrin-mediated endocytosis: The gateway into plant cells. Curr. Opin. Plant Biol. 2011, 14, 674-682. [CrossRef] [PubMed]

35. Thoma, S.; Hecht, U.; Kippers, A.; Botella, J.; de Vries, S.; Somerville, C. Tissue-specific expression of a gene encoding a cell wall-localized lipid transfer protein from arabidopsis. Plant Physiol. 1994, 105, 35-45. [CrossRef] [PubMed]

36. Van Loon, L.; van Strien, E. The families of pathogenesis-related proteins, their activities, and comparative analysis of PR-1 type proteins. Physiol. Mol. Plant Pathol. 1999, 55, 85-97. [CrossRef]

37. Roy-Barman, S.; Sautter, C.; Chattoo, B.B. Expression of the lipid transfer protein Ace-AMP1 in transgenic wheat enhances antifungal activity and defense responses. Transgenic Res. 2006, 15, 435-446. [CrossRef] [PubMed]

38. Li, X.; Gasic, K.; Cammue, B.; Broekaert, W.; Korban, S.S. Transgenic rose lines harboring an antimicrobial protein gene, Ace-AMP1, demonstrate enhanced resistance to powdery mildew (Sphaerotheca pannosa). Planta 2003, 218, 226-232. [CrossRef] [PubMed]

39. Cao, A.; Xing, L.; Wang, X.; Yang, X.; Wang, W.; Sun, Y.; Qian, C.; Ni, J.; Chen, Y.; Liu, D. Serine/threonine kinase gene $S t p k-V$, a key member of powdery mildew resistance gene Pm21, confers powdery mildew resistance in wheat. Proc. Natl. Acad. Sci. USA 2011, 108, 7727-7732. [CrossRef] [PubMed]

40. Pedley, K.F.; Martin, G.B. Molecular basis of Pto-mediated resistance to bacterial speck disease in tomato. Annu. Rev. Phytopathol. 2003, 41, 215-243. [CrossRef] [PubMed]

41. Yang, Y.; Shah, J.; Klessig, D.F. Signal perception and transduction in plant defense responses. Genes Dev. 1997, 11, 1621-1639. [CrossRef] [PubMed]

42. Ryu, H.-S.; Han, M.; Lee, S.-K.; Cho, J.-I.; Ryoo, N.; Heu, S.; Lee, Y.-H.; Bhoo, S.H.; Wang, G.-L.; Hahn, T.-R. A comprehensive expression analysis of the WRKY gene superfamily in rice plants during defense response. Plant Cell Rep. 2006, 25, 836-847. [CrossRef] [PubMed]

43. Trognitz, F.; Manosalva, P.; Gysin, R.; Niño-Liu, D.; Simon, R.; del Rosario Herrera, M.; Trognitz, B.; Ghislain, M.; Nelson, R. Plant defense genes associated with quantitative resistance to potato late blight in Solanum phureja $\times$ Dihaploid S. tuberosum hybrids. Mol. Plant-Microbe Interact. 2002, 15, 587-597. [CrossRef] [PubMed]

44. Bézier, A.; Lambert, B.; Baillieul, F. Study of defense-related gene expression in grapevine leaves and berries infected with Botrytis cinerea. Eur. J. Plant Pathol. 2002, 108, 111-120. [CrossRef]

45. Dao, T.; Linthorst, H.; Verpoorte, R. Chalcone synthase and its functions in plant resistance. Phytochem. Rev. 2011, 10, 397-412. [CrossRef] [PubMed]

46. Mohanta, T.K.; Occhipinti, A.; Zebelo, S.A.; Foti, M.; Fliegmann, J.; Bossi, S.; Maffei, M.E.; Bertea, C.M. Ginkgo biloba responds to herbivory by activating early signaling and direct defenses. PLOS ONE 2012, 7, e32822. [CrossRef] [PubMed]

47. Pezet, R.; Gindro, K.; Viret, O.; Spring, J.-L. Glycosylation and oxidative dimerization of resveratrol are respectively associated to sensitivity and resistance of grapevine cultivars to downy mildew. Physiol. Mol. Plant Pathol. 2004, 65, 297-303. [CrossRef]

48. Treutter, D. Significance of flavonoids in plant resistance: A review. Environ. Chem. Lett. 2006, 4, $147-157$. [CrossRef]

49. Persans, M.W.; Wang, J.; Schuler, M.A. Characterization of maize cytochrome p450 monooxygenases induced in response to safeners and bacterial pathogens. Plant Physiol. 2001, 125, 1126-1138. [CrossRef] [PubMed]

50. Qi, X.; Bakht, S.; Qin, B.; Leggett, M.; Hemmings, A.; Mellon, F.; Eagles, J.; Werck-Reichhart, D.; Schaller, H.; Lesot, A. A different function for a member of an ancient and highly conserved cytochrome p450 family: From essential sterols to plant defense. Proc. Natl. Acad. Sci. USA 2006, 103, 18848-18853. [CrossRef] [PubMed] 
51. Whitbred, J.M.; Schuler, M.A. Molecular characterization of cyp73a9 andcyp82a1 p450 genes involved in plant defense in pea. Plant Physiol. 2000, 124, 47-58. [CrossRef] [PubMed]

52. Kim, Y.-C.; Kim, S.-Y.; Paek, K.-H.; Choi, D.; Park, J.M. Suppression of cacyp1, a novel cytochrome p450 gene, compromises the basal pathogen defense response of pepper plants. Biochem. Biophys. Res. Commun. 2006, 345, 638-645. [CrossRef] [PubMed]

53. Narusaka, M.; Seki, M.; Umezawa, T.; Ishida, J.; Nakajima, M.; Enju, A.; Shinozaki, K. Crosstalk in the responses to abiotic and biotic stresses in arabidopsis: Analysis of gene expression in cytochrome p450 gene superfamily by cDNA microarray. Plant Mol. Biol. 2004, 55, 327-342. [CrossRef] [PubMed]

54. Deák, M.; Horváth, G.V.; Davletova, S.; Török, K.; Sass, L.; Vass, I.; Barna, B.; Király, Z.; Dudits, D. Plants ectopically expressing the ironbinding protein, ferritin, are tolerant to oxidative damage and pathogens. Nat. Biotechnol. 1999, 17, 192-196. [PubMed]

55. Arnaud, N.; Murgia, I.; Boucherez, J.; Briat, J.-F.; Cellier, F.; Gaymard, F. An iron-induced nitric oxide burst precedes ubiquitin-dependent protein degradation for arabidopsis atfer1 ferritin gene expression. J. Biol. Chem. 2006, 281, 23579-23588. [CrossRef] [PubMed]

56. Yang, J.; Liu, S.; Yang, X.; Zhang, M. Chloroplast-located BjFer1 together with anti-oxidative genes alleviate hydrogen peroxide and hydroxyl radical injury in cytoplasmic male-sterile Brassica juncea. Mol. Biol. Rep. 2012, 39, 4169-4176. [CrossRef] [PubMed]

57. Liu, G.; Greenshields, D.L.; Sammynaiken, R.; Hirji, R.N.; Selvaraj, G.; Wei, Y. Targeted alterations in iron homeostasis underlie plant defense responses. J. Cell Sci. 2007, 120, 596-605. [CrossRef] [PubMed]

58. Keogh, R.; Deverall, B.; McLeod, S. Comparison of histological and physiological responses to Phakopsora pachyrhizi in resistant and susceptible soybean. Trans. Br. Mycol. Soc. 1980, 74, 329-333. [CrossRef]

59. Wolf, G.; Fric, F. A rapid staining method for Erysiphe graminis f. Sp. hordei in and on whole barley leaves with a protein-specific dye. Phytopathology 1981, 71, 596-598.

60. Xu, J.; Aileni, M.; Abbagani, S.; Zhang, P. A reliable and efficient method for total RNA isolation from various members of spurge family (Euphorbiaceae). Phytochem. Anal. 2010, 21, 395-398. [CrossRef] [PubMed]

61. Liang, P.; Zhu, W.; Zhang, X.; Guo, Z.; O'Connell, R.P.; Averboukh, L.; Wang, F.; Pardee, A.B. Differential display using one-base anchored oligo-dT primers. Nucleic Acids Res. 1994, 22, 5763. [CrossRef] [PubMed]

62. Minglin, L.; Yuxiu, Z.; Tuanyao, C. Identification of genes up-regulated in response to Cd exposure in Brassica juncea L. Gene 2005, 363, 151-158. [CrossRef] [PubMed]

63. Xu, J.; Yin, H.; Wang, W.; Mi, Q.; Liao, X.; Li, X. Identification of Cd-responsive genes of Solanum nigrum seedlings through differential display. Plant Mol. Biol. Rep. 2009, 27, 563-569. [CrossRef]

64. Rahman, A.Y.A.; Usharraj, A.O.; Misra, B.B.; Thottathil, G.P.; Jayasekaran, K.; Feng, Y.; Hou, S.; Ong, S.Y.; $\mathrm{Ng}$, F.L.; Lee, L.S. Draft genome sequence of the rubber tree Hevea brasiliensis. BMC Genom. 2013, 14, 75. [CrossRef] [PubMed]

65. Li, H.; Qin, Y.; Xiao, X.; Tang, C. Screening of valid reference genes for real-time RT-PCR data normalization in Hevea brasiliensis and expression validation of a sucrose transporter gene HbSUT3. Plant Sci. 2011, 181, 132-139. [CrossRef] [PubMed]

(C) 2016 by the authors; licensee MDPI, Basel, Switzerland. This article is an open access article distributed under the terms and conditions of the Creative Commons by Attribution (CC-BY) license (http://creativecommons.org/licenses/by/4.0/). 